УДК 341.225.5+(656.61.052.4:621.398)

DOI https:// doi.org/10.32837/yuv.v0i6.2054

О. Краснікова,

кандидат юридичних наук, доцент,

доцент кафедри морського права

Національного університету «Одеська морська академія»

\title{
ТЕНДЕНЦІЇ ТРАНСФОРМАЦІЇ МІЖНАРОДНОГО МОРСЬКОГО ПРАВА ЯК НАСЛІДОК УПРОВАДЖЕННЯ АВТОНОМНИХ СУДЕН
}

Вступ. Розвиток інформаційних технологій формує глобальну тенденцію на автономізацію виробничих і транспортних процесів у різних галузях промисловості, сферах послуг та логістичних системах. Нині існують і активно використовуються автономні засоби різного виду транспорту, адже світовій практиці відомі приклади автоматизованих метрополітенів та автоматично керованих транспортних засобів на сучасних контейнерних терміналах, фахівцями у сфері авіації на основі концепції автономного управління розроблені та використовуються безпілотні літальні апарати, те ж саме відбувається щодо приватних перевезень автомобілем. Зазначене дає змогу дійти висновку, що автономне керування транспортними засобами $є$ міжгалузевим світовим трендом, в стороні від якого не залишився водний транспорт.

У щорічному огляді морського транспорту, підготовленого Конференцією ООН з торгівлі та розвитку за 2018 рік, акцентується увага на тому, що в сучасному світі використання інформаційних технологій у морській сфері спостерігається в чотирьох взаємопов'язаних напрямах. Точніше, вони являють собою єдиний потік інновацій у морській галузі. Серед них слід назвати питання безпеки, особливо кібербезпеки, розвиток Інтернету, зокрема Інтернету речей, а також застосування технології блокчейн i подальше впровадження автоматизації суден, аж до повністю автономних суден [1]. Щодо останніх, то зазначені технології будуть включати передові системи підтримки прийняття рішень для забезпечення можливості дистанційної експлуатації суден під частковим або повністю автономним управлінням.

Разом із питаннями безпеки мореплавання, які, безумовно, будуть супроводжувати використання автономних суден, виникають різні юридичні колізіі, пов'язані з наявністю в міжнародному та національному морському праві норм, що регулюють сучасне правове становище судна та екіпажу. Так, наприклад, відомо, що будь-яке судно, яке знаходиться у відкритому морі без екіпажу на борту, вважається судном-привидом або нічийним (безхазяйним) майном.

Актуальність дослідження зумовлена тим, що технічні розробки й реальна можливість експлуатації автономного флоту випереджають ступінь розробленості правового регулювання цього феномена. Сучасна нормативна база, що регулює діяльність водного транспорту, не здатна забезпечити безпечну експлуатацію автономних суден, оскільки міжнародні й національні нормативні акти розраховані на перебування на борту судна живих людей, які керують судном, а саме членів екіпажу. Лише кілька років тому Міжнародна морська організація приступила до обговорення питань, що стосуються 
автономних суден, які не вписуються в наявну правову парадигму регулювання судноплавства. Однак поява автономних суден і подальша перспектива їх експлуатації, крім прийняття нових норм і стандартів, приводить до необхідності внесення істотних змін у чинні міжнародні конвенції щодо судноплавства.

У наукових колах дослідження безпілотних, автономних морських суден проводилися з різних позицій, але здебільшого вони стосувалися втілення інноваційних технологій, спрямованих на скорочення експлуатаційних витрат у морській індустрії. Однак лише недавно в національних та зарубіжних джерелах з'явилися статті, що акцентують увагу на правових проблемах, пов'язаних зі впровадженням автономних суден [2, с. $13-15 ; 3$, с. 65-70]. Незначна кількість публікацій обумовлена недавньою появою та стрімким розвитком цього феномена.

Постановка завдання. У публікації проведено дослідження підготовчих заходів і процедур, що проводяться Комітетом з безпеки на морі Міжнародної морської організації, щодо можливості нормативного забезпечення функціонування автономних надводних суден, у зв'язку з чим розглянуто можливі шляхи трансформації морського права.

Результати дослідження. Міжнародна дискусія щодо автономних або безпілотних суден, що отримала значного імпульсу останніми роками, нещодавно досягла головного міжнародного регулюючого органу в галузі судноплавства, а саме Міжнародної морської організації (далі - IMO). Відправною точкою стало рішення, прийняте Організацією у 2017 році, про проведення аналітичного огляду проблем, пов'язаних зі впровадженням морських автономних надводних суден [4].

Сучасна тенденція морської індустрії полягає в тому, що безпілотні технології стрімко набирають обертів [5]. Однак коли йдеться про судна й мореплавання, то слід мати на увазі, що законодавець часто ставить захист моряків і морського середовища на місце своїх чільних пріоритетів, відсуваючи навігаційні або комерційні аспекти, які також виникають у результаті використання автономних суден. Цей аспект відіграє важливу роль під час оцінювання термінів впровадження зазначених інновацій.

Отже, влітку 2017 року на дев'яносто восьмій сесіі Комітету IMO 3 безпеки на морі (англ. Maritime Safety Committee) (далі - MSC) було прийнято рішення щодо проведення регулятивного огляду щодо морських автономних надводних суден (англ. Maritime Autonomous Surface Ships) (далі - MASS) [3]. 3 урахуванням пропозицій, що надійшли від держав, уже на наступній сесії MSC у 2018 році була заснована спеціальна робоча група, яка виконала роботу з визначення області регулятивного огляду, включаючи цілі, завдання, методологію, інструменти, тип і розмір суден, попередні визначення, різні типи й концепції автономії, автоматизаціі, експлуатації та укомплектування екіпажом [6].

Відповідно до правил юридичної техніки, розроблення правового регулювання будь-якої сфери має починатися з визначення дефініцій, у зв'язку 3 чим слід закріпити саме поняття автономного судна, тому робочою комісією було запропоновано визначення MASS як «судна, здатного через автоматичний процес забезпечити процес прийняття рішень або можливість функцій людини щодо часткового або повного контролю і керування судном незалежно від того, здійснюється це на борту судна або в якому-небудь іншому місці» [7].

Розробники поняття постаралися визначити автономне судно максимально широко, оскільки технічний ступінь розробленості таких суден передбачає різні рівні його автономності. У зв'язку з цим MSC були визначені чотири таких рівні залежно від ступеня участі людей в управлінні судном. 
MSC вказав на мету діяльності робочої комісії, якою є встановлення того, наскільки безпечно й екологічно може бути забезпечено використання MASS за допомогою як наявних інструментів IMO, так і тих, що будуть розроблятися.

Роботу було запропоновано виконати у два етапи. На першому етапі для оцінювання проблем, які створюють різні рівні автономізації судна, передбачалося визначити, які 3 діючих інструментів IMO допускають i не допускають практичну реалізацію та експлуатацію MASS, а також потребують змін. На цьому етапі були прийняті для розгляду такі обов'язкові інструменти IMO, як Конвенція про Міжнародні правила запобігання зіткненню суден на морі 1972 року (COLREGS-72); Міжнародна конвенція 3 охорони людського життя на морі 1974 року, а також Протоколи до неї (SOLAS-74/78); Конвенція про вантажну марку 1966 року з Протоколами до неї (Convention LL-66); Міжнародна конвенція по обмірюванню суден 1969 року (Convention ТМ-69); Міжнародна конвенція про пошук і рятування на морі 1979 року (SAR 79); Міжнародна конвенція про підготовку i дипломування моряків та несення вахти 1978 року (STCW 78); Міжнародна конвенція про стандарти підготовки, дипломування та несення вахти екіпажами рибальських суден 1995 року (STCW-F); Міжнародна конвенція про безпечні контейнери 1972 року (CSC-72); нормативні документи для пасажирських суден (Угода по пасажирським суднам, які здійснюють спеціальні перевезення, 1971 року (STP), Протокол про вимоги до приміщення на пасажирських суднах, зайнятих у спеціальних перевезеннях, 1973 року (SPACE STP); Угода 1996 року щодо окремих вимог по остійності для пасажирських суден типу ро-ро, що здійснюють регулярні плановані міжнародні рейси між/в/з певних портів у Північно-Західній Європі і на Бал- тійському морі (Стокгольмська угода 1996 року)).

Результатом регулятивного огляду, який проводить робоча група, має стати звіт, у якому будуть визначені ті положення в документах IMO, які застосовні до MASS, але можуть перешкоджати функціонуванню MASS; можуть бути застосовні до MASS і не виключають функціонування MASS, а також не вимагають внесення будьяких змін; застосовні до MASS і не виключають функціонування MASS, але можуть вимагати внесення змін, поправок або уточнень документів IMO; нарешті, не застосовні до функціонування MASS, оскільки вони пов'язані 3 присутністю людини на борту судна [8].

На другому етапі будуть проаналізовані потенційні нормативні можливості для вирішення виявлених проблем. 3 урахуванням людського елементу, технологічних та експлуатаційних факторів передбачається визначити найбільш підходящий спосіб забезпечення функціонування MASS $з$ використанням стандартних підходів до нормативної юридичної техніки, а саме внесення поправок в наявні інструменти; використання рівноцінних замін та еквівалентів, вилучень, передбачених інструментами IMO, або розроблення інтерпретацій; розроблення нових інструментів, або в результаті проведеного нормативного аналізу необхідно буде запропонувати якісно новий підхід до вирішення зазначеної проблеми. Результати роботи комісії мають бути представленими у 2021 році, при цьому вони не включають розроблення будь-яких нормативних правил у цій галузі.

В цей процес включилися інші міжнародні органи та об'єднання держав. Так, у січні 2020 року в рамках Європейського агентства морської безпеки (структура, заснована Європейським Союзом, - EMSA) була створена горизонтальна цільова група, щоби стати технічним посередником щодо 
автономних суден, зокрема стати платформою для технічних обговорень 3 морськими адміністраціями, судновласниками і науковими колами.

До цього, а саме у 2019 році, EMSA замовила дослідження SAFEMASS (дослівно - Безпека автономного надводного судна), щоб виявити нові ризики й прогалини в нормативних актах, які з'являться під час упровадження суден різного рівня автономії. Підготовлений за результатами дослідження звіт буде корисний у подальшій роботі головного морського міжнародного регулюючого органу [9].

В серпні 2020 року представники КНР, Японії, Данії, Норвегіi, Нідерландів, Фінляндіі, Республіки Корея, Сінгапуру, а також представники IMO, Міжнародної асоціації морських засобів навігаційного обладнання та маякових служб, Міжнародної асоціації портів і гаваней зустрілися на віртуальному заході, щоб запустити ініціативу MASSPorts, що являє собою мережу, створену державами й неурядовими організаціями для вирішення проблем і досягнення гармонізації стандартів під час випробувань та експлуатації морських автономних надводних суден у портах [10].

Завдання досліджень полягає не тільки в тому, щоби побудувати прототипи безпілотних суден, але й розробити всю інфраструктуру, яка буде обслуговувати цей вид транспорту, зробити іï безпечною для людей i навколишнього середовища, а також економічно доцільною.

У червні 2019 року MSC продовжив роботу 3 питань автономних суден, отже, в рамках сто першої сесії був затверджений циркуляр MSC.1/Circ.1604 «Тимчасове керівництво з випробувань суден MASS». Це Керівництво було розроблено задля надання допомоги відповідним органам і зацікавленим сторонам із забезпеченням безпечного проведення випробувань систем та інфраструктури, пов'язаної із судами MASS, за дотримання необхідного рівня захисту навколишнього середовища [11].

Тимчасове керівництво включає опис основних принципів і цілей проведення випробувань, заходів 3 оцінювання ризиків, кваліфікації персоналу, залученого до випробування, опис інфраструктури, комунікації та обміну даними під час проведення обмежених у часі випробувань нового обладнання, окремих систем і MASS загалом. Делегати 101-ї сесії MSC погодилися включити в Керівництво розділ, який має назву «Менеджмент ризиків», та визначили, що це $€$ одним із принципів та основних цілей документа. 3 огляду на те, що плани дій та заходи щодо аварійних ситуацій під час випробування суден MASS відіграватимуть одну 3 ключових ролей у менеджменті ризиків, делегати погодилися включити їх до менеджменту ризиків.

Поява автономних суден усіх рівнів спричинить необхідність перегляду норм, що встановлюють вимоги до екіпажу, а також до його кількісного та якісного складу. Буде потрібне розроблення заходів з підготовки та дипломування членів екіпажів таких суден і берегового персоналу, здатних управляти автономними судами й обслуговувати їх. Безсумнівно, з'являться нові суднові посади, наприклад зовнішній капітан або береговий екіпаж, фахівець із морської охорони й кібербезпеки. Крім того, впровадження безекіпажних суден стане передумовою для зміни нормативно-правового регулювання трудових правовідносин у судноплавстві, тому що відпаде необхідність забезпечення життєдіяльності людей на судні.

На жаль, на запланованій 102-й сесії MSC, яка вперше пройшла дистанційно в листопаді поточного року, не були порушені питання щодо MASS. Ця обставина, ймовірно, пов'язана 3 тим, що через пандемію COVID19 чергова сесія MSC була перенесена з весни 2020 року, тому залишила під 
питанням безліч першочергових проблем. Отже, рішення, пов'язані з автономними надводними судами, міжнародному співтовариству доведеться прийняти в наступні роки.

Висновки. Вторгнення автономного судноплавства на ринок морських перевезень неминучий, і перед IMO стоїть завдання привести чинні міжнародні норми й стандарти у сфері морського права у відповідність до останніх технологічних розробок. За відсутності будь-яких нормативних вказівок із боку IMO окремі держави прапора судна можуть взяти на себе ініціативу інтерпретувати міжнародні вимоги, що само по собі є виправданням для невідкладного проведення міжнародної гармонізації в цій галузі.

Ймовірно, тривалий час нормативне регулювання буде змішаним, що враховує експлуатацію автономних суден і суден, традиційно керованих екіпажами на борту. Попереду y IMO великий обсяг роботи, оскільки технічні стандарти для автоматизованої ситуаційної обізнаності, віддаленого управління судами й прийняття рішень мають бути розроблені з нуля разом із більш загальними вимогами щодо кібербезпеки, правозастосування, навчання, сертифікації тощо.

Однак у довгостроковій перспективі нові елементи, які виникнуть у результаті експлуатації автономних суден, вказують на користь прийняття нового регулюючого інструменту або обов'язкового кодексу, спеціально присвяченого цьому питанню. Основна проблема буде полягати в необхідності розробити широкий спектр нових правил і стандартів. Навіть якщо повністю автономні судна, що курсують по океанах без будь-якої участі людини, можуть залишатися далекою перспективою, то необхідність створення правової основи діяльності для періодично безпілотних суден або суден, які частково управляються автономними навігаційними системами, вже існує, адже зрозуміло, що тимчасового або поетапного оновлення правил недостатньо. Правила повинні, наскільки це можливо, містити положення, які самі оновлюються, тому здатні задовольнити поточні та майбутні технологічні досягнення.

Публікація присвячена дослідженню нормативних процедур щзодо правового забезпечення впровадження в морську галузь таких сучасних інноваційних технологій, як автономні надводні морські судна. Аналізується підготовча діяльність Комітету IMO з безпеки на морі, яка спрямована на вирішення нормативно-правових питань, що виникають під час введення в експлуатацію таких інновациій.

Охарактеризовано роботу створеної Комітетом спеціальної робочої групи. Метою ї̈ роботи позначено проведення регулятивного огляду для того, щоби встановити, наскільки безпечно й екологічно може бути забезпечено використання автономних суден за допомогою сучасних та нових інструментів IMO.

3 аналізу циикулярів $і$ звітів робочої групи встановлено поетапність ї̈ роботи. Створений допоміжний орган перш за все повинен оцінити, які з чинних міжнароднuх актів IMO допускають $i$ не допускають існування та експлуатацію автономних суден. Для изього прийняті до розгляду найбільш обов'язкові, з точки зору робочої групи, інструменти IMO. Серед них слід назвати SOLAS-74/78, COLREGS-72, STCW 78, SAR 79, Convention LL-66, Convention TM-69.

Після завершення другого етаnу робоча група, використовуючи стандартні підходи до нормативної юридичної техніки, повинна запропонувати найбільш підходящцй спосіб трансформації наявних норм міжнародного морського права для правового регулювання функціонування автономних суден. 
В рамках дослідження акиентується увага на цииркулярі IMO «Тимчасове керівниитво з випробувань автономних суден», який прийнятий у рамках передостанньої сесії Комітету для надання допомоги державним органам і зацікавленим особам під час проведення випробувань систем та інфраструктури, пов'язаної з автономними суднами.

Проблемами інтеграціi автономних суден у сферу судноплавства защікавилися інші міжнародні органи, міннародні неурядові об’єднання та окремі держави. Щодо цьього у статmі характеризуються науково-дослідницька програма EMSA (дослідження SAFEMASS), проєкт MASSPorts, створений для досягнення гармонізації міннародних стандартів під час випробувань та експлуатації автономних суден y nорmax.

В результаті дослідження зроблено висновок про те, що в перспективі нормативне регулювання з аналізованого питання буде змішаним, шзо враховуе експлуатацію автономних суден $i$ суден, традиційно керованих екіпажами на борту. Однак у майбутньому $\epsilon$ необхідність прийняти нового регулятивного інструменту, спеціально присвяченого иьому питанню.

Ключові слова: інновації в морській галузі, автономне судно (MASS), інструменти IMO, Комітет 3 безпеки на морі, кібербезпека.

Krasnikova O. Trends in a transformation of the international martime law as a consequence of the introduction of autonomous vessels

The publication is devoted to study of legal procedures that must be carried out in order to introduce innovative technologies into the maritime industry. We are talking about Maritime Autonomous Surface Ships (MASS). The article analyzes the activity of Maritime Safety
Committee. Its activity is preparatory in solving legal issues that arise when commissioning autonomous ships. The author analyzes the work of a special working group, which was created by the Committee. The aim of the special working group is to conduct the Regulatory scoping exercise. The scoping should establish how, using modern IMO tools, to ensure safe and environmentally friendly use of autonomous ships.

The author points out that the working group is working in two stages. First of all, the group should assess which existing international IMO instruments allow and do not allow the operation of autonomous ships. To this end, the working group is examining important international documents that have been adopted by IMO. Among them there are SOLAS-74/78, COLREGS-72, STCW 78, SAR 79, Convention LL-66, Convention TM-69 and others.

After completing the second phase of the work, the group should propose the most appropriate way to transform the existing rules of international maritime law. The group should indicate the standard approaches of normative legal technique. It is necessary in order to make it easy to regulate the functioning of autonomous ships.

For the purposes of this study, the author refers to the circular as the Interim Guidelines for MASS trials. The document was adopted at the penultimate session of the Committee. It is needed to help governments and stakeholders test systems and infrastructure that relate to autonomous ships.

The author points out that other international bodies, as well as international non-governmental associations, are interested in the problems of integrating autonomous ships into the field of shipping. In this regard, the article describes the EMSA research program, which 
conducted the SAFEMASS study, as well as the MASS Ports project.

As a result of the study, it was concluded that in the long term, the normative regulation of using autonomous ships will be mixed. It means that the operation of autonomous ships and ships that are traditionally operated by crews on board will be taken into account. However, it is stated that in the long term a new regulatory instrument, which will be specifically devoted to this issue, is needed to be adopted.

Key words: Maritime Autonomous Surface Ships (MASS), Maritime Safety Committee, innovative technologies, IMO tools, cybersecurity.

\section{Лiтература}

1. UNCTAD/RMT/2018: Обзор морского транспорта - 2018 год (Конферениия ЮНКТАД). Резюме, август 2019 года. URL: https:// unctad.org/system/files / official-document/rmt2018_ru.pdf.

2. Клюев В.В. Правовое регулирование использования автономных судов. Tранспорт Российской Федеращии. 2018. № 5 (78). С. 13-15.

3. Плачкова Т.м. Адміністративно-правове забезпечення безпеки мореплавства в Україні: дис. ... докт. філософ. : спещ. 081 ; НУ «ОЮА». Одеса, 2020. 216 c.

4. Iwanaga Sh. Legal issues relating to the maritimeautonomoussurfaceships' development and introduction to services (2019) / / World Maritime University Dissertations. 1190. URL: https: / / commons.wmu.se / all_ dissertations $/ 1190$.

5. MSC 98/20/13. April 13, 2017. URL: https: / / www.imo.org/en/MediaCentre/ MeetingSummaries / Pages / MSC-98thsession.aspx.
6. NYK Conducts World's First Maritime Autonomous Surface Ships Trial. (NYK Line) 30.09.2019. URL: https: // wwr.nyk.com/ english/news/2019/20190930_01.html.

7. Автономне судно Mayflower з технологією від SBM пройде перші випробування. World news platform. 2020. URL: https: / / theworldnews.net / ua-news / avtonomne-sudno-mayflower-z-tekhnologiieiuvid-ibm-proide-pershi-viprobuvannia.

8. Maritime Safety Committee (MSC), 99th session. May 16-25, 2018. URL : https: / / www.imo.org / en/MediaCentre; Meeting Summaries / Pages / MSC-99thsession.aspx

9. IMO takes first steps to address autonomous ships. PressBriefing 08/2018. URL: https: / / www.imo.org/en/ MediaCentre / PressBriefings / Pages / 08MSC-99-MASS-scoping.aspx.

10. Regulatory scoping exercise for the use of maritime autonomous surface ships (MASS). Plan of approach for the scoping exercise: MSC 99/5/5. March 12, 2018. URL: https: / / wrw.setfords.co.uk/ wp-content/uploads / MSC9955.pdf.

11. Study of the risks and regulatory issues of specific cases of MASS - Summary European Maritime Safety Agency (EMSA). Report No. 2020-0279, Rev. O. Document No. 11GG2XH6-3. Date: 2020-03-25. URL: http: / / www.emsa.europa.eu/ mass.html.

12. Восемь стран-иленов IMO запустили инициативу по развитию автономного судоходства. Эл. Изд-во Логист. Today. 2020. URL: https://logist.today/ dnevnik_logista/2020-08-07/vosemstran-chlenov-imo-zapustili-iniciativu-porazvitiju-avtonomnogo-sudohodstva.

13. Interim guidelines for MASS trials: MSC.1/Circ.1604. June 14, 2019. URL: https: / / wwwcdn.imo.org / localresources/ en / MediaCentre / Hot Topics / Documents /MSC.1-Circ.1604\%20-\%20 Interim \% 20 Guidelines \% 20 For\% 20 Mass\% 20Trials\%20(Secretariat).pdf. 